\title{
MICROFOSSIL SEQUENCES IN ILPONLAMPI, A SMALL LAKE IN NORTHERN RUSSIAN KARELIA
}

\author{
ANTTI HUTTUNEN, RAIJA-LIISA HUTTUNEN, ILPO \\ EKMAN, KRISTIINA ESKONEN, LEO KOUTANIEMI \\ and YRJÖ VASARI
}

HUTTUNEN, ANTTI; HUTTUNEN, RAIJA-LIISA; EKMAN, ILPO; ESKONEN, KRISTIINA; KOUTANIEMI, LEO and VASARI, YRJÖ 1994. Microfossil sequences in Ilponlampi, a small lake in northern Russian Karelia. Bull. Geol. Soc. Finland 66, Part 2, 67-80.

The Holocene history of Ilponlampi, a small lake situated in northwestern Russian Karelia, is presented based on pollen, diatom, charred particle and botanical macroremain analyses. Four 14-C dates for the sequence show that it reaches back almost to the beginning of the Holocene. The immigration of the various tree species took place somewhat earlier than further west. A natural acidification process is characteristic of the lake, which seems to have remained practically unaffected by any human influence.

Key words: Paleoecology, history of vegetation, pollen, Bacillariophyceae, diatomae, charcoal, Holocene, Russian Karelia.

Antti Huttunen and Raija-Liisa Huttunen: Department of Botany, University of Oulu, 90570 Oulu, Finland.

Ilpo Ekman: Institute of Geology, Academy of Sciences, 185610 Petrozavodsk, Russia.

Kristiina Eskonen: Karelian Institute, Sect. Ecology, University of Joensuu, 80101 Joensuu, Finland.

Leo Koutaniemi: Department of Geography, University of Oulu, 90570 Oulu, Finland.

Yrjö Vasari: Department of Botany, 00014 University of Helsinki, Finland. 


\section{INTRODUCTION}

The biogeographical Kuusamo region (Regio kuusamoënsis) consisting of the Kuusamo upland and crossed by the boundary between Russia and Finland since the Second World War, is well known for the richness of its biota, flora and fauna alike. One concrete proof of the biogeographical importance of the region is the fact that national parks have been established on both sides of the boundary, Oulanka National Park in Finland and Paanajärvi National Park in Russian Karelia.

Much research carried out on either side of the boundary has helped us to acquire quite an intimate knowledge of the Quaternary history of the Kuusamo region, too (see Vasari 1962; Vasari \& Huttunen 1984; Jelina 1981, 1985). The aim of the present work was to generate data for an otherwise poorly known area in the Paanajärvi National Park which is likely to have emerged from under the ice quite early.

\section{AREA STUDIED}

There is a small lake with no name on the map, called by us 'Ilponlampi' ( $66^{\circ} 07^{\prime} 24^{\prime \prime}$ N, $30^{\circ} 14^{\prime}$ $57^{\prime}$ ' E, c. $285 \mathrm{~m}$ asl), situated about $1.5 \mathrm{~km}$ south of the top of the hill of Nuorunen, about one hundred metres below the forest limit (Fig. 1). It lies some 30 $\mathrm{km}$ inside of innermost Late-Glacial end moraine (Ss II, Kalevala; Ekman \& Iljin 1991), but there are still some uncertainties in correlating these formations with the ice retreat phases and in the timescale (see Saarnisto 1991).

Ilponlampi is about a hectare in size, and having no clear flow through, it forms an ideal object for paleoecological investigations. The water depth at the coring site in the middle of the lake was $293 \mathrm{~cm}$, and the sediment sampled was $234 \mathrm{~cm}$ in thickness.

The major part of the surroundings is covered by virgin spruce-dominated coniferous forests of the north boreal vegetation zone and mires belonging to the southern north boreal aapa mire vegetation zone (Eurola \& Vorren 1980). The mires exist mostly in valleys, which are often oriented west east.

The nearby top of Nuorunen is dominated by a virgin ericoid and lichenous hemioroarctic vegetation(Kalliola 1939; Huttunen \& Vasari 1994). The forest limit varies in height between $340-400 \mathrm{~m}$ a.s.l. on the nearest (south-facing) slope, and is generally between $340-500$ metres a.s.1.

\section{METHODS}

The samples were taken with a Russian-type peat sampler from the ice in April 1991. Organic matter expressed as loss-on-ignition, was determined by combustion for $4 \mathrm{~h}$ at $500^{\circ} \mathrm{C}$.

The palynological method used followed the acetolysis procedure with the addition of a known sum of exotic particles (Stockmarr 1971). The average pollen sum (AP + NAP) counted for each of 48 spectra at $5 \mathrm{~cm}$ intervals was 773 grains. The percentages of the pollen types were calculated based on the terrestrial pollen sum $(\Sigma \mathrm{P})$ and the proportions of other groups were on $\Sigma \mathrm{P}+\mathrm{n}$. Betula pollen was divided into two taxa, $B$. nana-type being distinguished separately on criteria of size and morphological features (based on measurements of reference grains at the Department of Botany, University of Oulu), even though these characters are not always particularly clear. Charred particles were counted separately in two size classes $(\leq 25 \mu$ and $>25 \mu$ ), and the results are given as percentages of $\Sigma \mathrm{P}+\mathrm{n}$.

14-C and 13-C analyses of four and five samples respectively were performed at the Institute of Geology, Estonian Academy of Sciences, Tallinn. The conventional Libby's value of $5568 \pm 30$ years was used for the half life of 14-C.

The material that was left after samples had been taken for pollen, diatom and loss-on-ignition analyses was used for the examination of macroscopic plant remains by the procedure described in Vasari (1962).

The diatom analysis was carried out at $5 \mathrm{~cm}$ intervals, except between 10 and $110 \mathrm{~cm}$, where it 


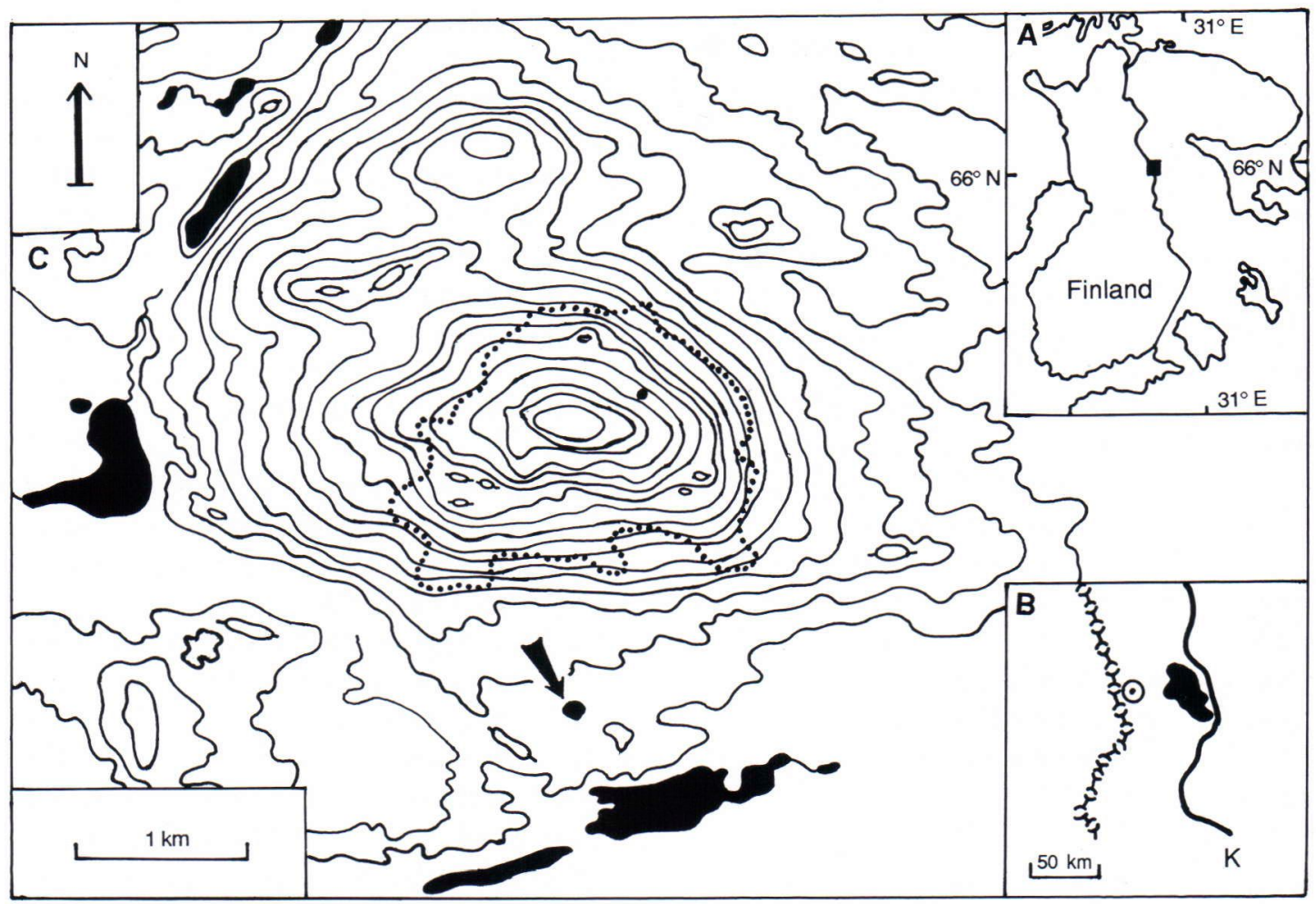

Fig. 1. The site of Ilponlampi $(C)$, west of the Kalevala end moraines (marked by K in section B, where the hill of Nuorunen is indicated by a circle). The dotted line denotes the forest limit. The contour line interval is 20 metres.

was at $10 \mathrm{~cm}$ intervals. A small amount of sediment was diluted in pure alcohol and carefully homogenized with a glass rod. The solution was ultrasonicated to disaggregate the particles, and the slides were mounted in Naphrax. The efficiency of this rapid method has been verified before with traditional $\mathrm{H}_{2} \mathrm{O}_{2}$ and $\mathrm{HNO}_{3}$ oxidations (Sandman et al. 1990). 300-500 frustules were counted at each level, employing the keys of Mölder \& Tynni (1967-73) and Krammar \& Lange-Bertalot (1986-92) for identification purposes. The ecological charasteristics of the species are also based on these publications.

The "diatom $\mathrm{pH}$ " was reconstructed in accordance with both index $\alpha$ (Meriläinen 1967) and index B (Renberg \& Hellberg 1982). The figures were drawn with the computer program
TILIA, which is designed for the statistical and graphical handling of biostratigraphical data. Edward \& Cavalli-Sforza's stratigraphically constrained chord distance dendrogram was applied to the diagram to illustrate the stratigraphic division of the data. The total diatom data set was treated by Detrended Correspondence Analysis under TILIA program; no data transformation was necessary.

\section{RESULTS}

At the bottom of the core a silt with low loss-on-ignition changes abruptly to gyttja, the organic content of which is about $40 \%$ and increases to about $60 \%$ in the lake mud nearer the surface of the deposit (Fig 2). 


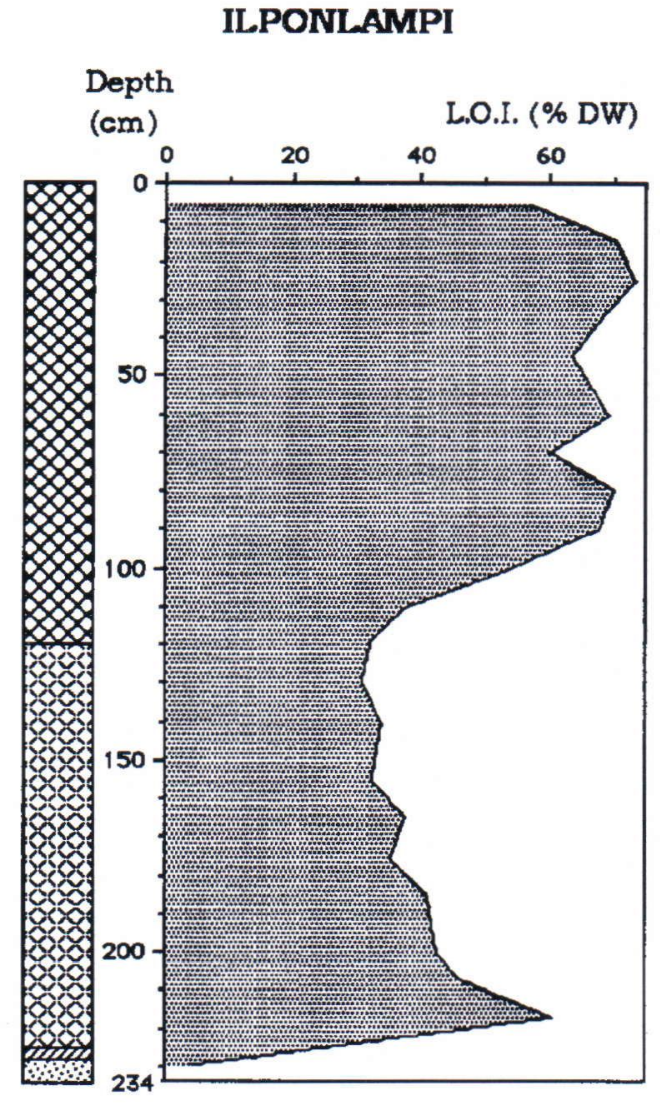

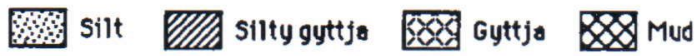

Fig. 2. Loss-on-ignition in the Ilponlampi core.

The radiocarbon dates obtained are:

$\begin{array}{llll}\text { Depth } & 14-\mathrm{C} \text { age } & \text { S.D. } & \Delta 13-\mathrm{C} \\ \mathrm{cm} & \mathrm{yr} & \mathrm{yr} & \% \\ 50-60 \mathrm{~cm} & 2875 & 95 & -29.6 \\ 100-110 \mathrm{~cm} & 4265 & 115 & -30.8 \\ 143-153 \mathrm{~cm} & - & - & -31.3 \\ 192-197 \mathrm{~cm} & 9005 & 115 & -27.9 \\ 218-228 \mathrm{~cm} & 9870 & 110 & -26.4\end{array}$

The rate of sedimentation as calculated from the radiocarbon ages remains fairly constant (Fig. 3), accumulation varying between 0.19 and $0.36 \mathrm{~mm} /$ $\mathrm{yr}$, with a mean rate of $0.23 \mathrm{~mm} / \mathrm{yr}$. A sample of one cubic $\mathrm{cm}$ thus represents 42.4 years, and the resolution of the pollen diagram is an average of 206 radiocarbon years.

The relative pollen and charcoal diagram (Fig. 4) has been divided into pollen assemblage zones (paz) mainly on the three-zone structured criteria for Eastern Finland introduced by Vasari (1962, H12-H14) and modified by Hyvärinen (1972, R. paz). The first zone (IL 1) is characterised by the dominance of birch pollen together with herb-rich spectra at the beginning (IL 1a). Artemisia-type reaches a value $3.0 \%$ at its maximum and Chenopodiaceae $1.6 \%$. Both Sorbus and Populus pollen can already be detected near the bottom of the core. Betula maximum begins with organic deposition $9870 \pm 110$ years B.P.

Alnus pollen exceeds $1 \%$ at the boundary to paz IL $29005 \pm 115$ years B.P., pine having already become the dominant tree pollen. Somewhat later (paz IL 2b) birch pollen abruptly resumes dominance from pine just after the decrease in the proportions of both small and large charcoal particles.

Paz IL 3 represents by the abiegnic time. No date

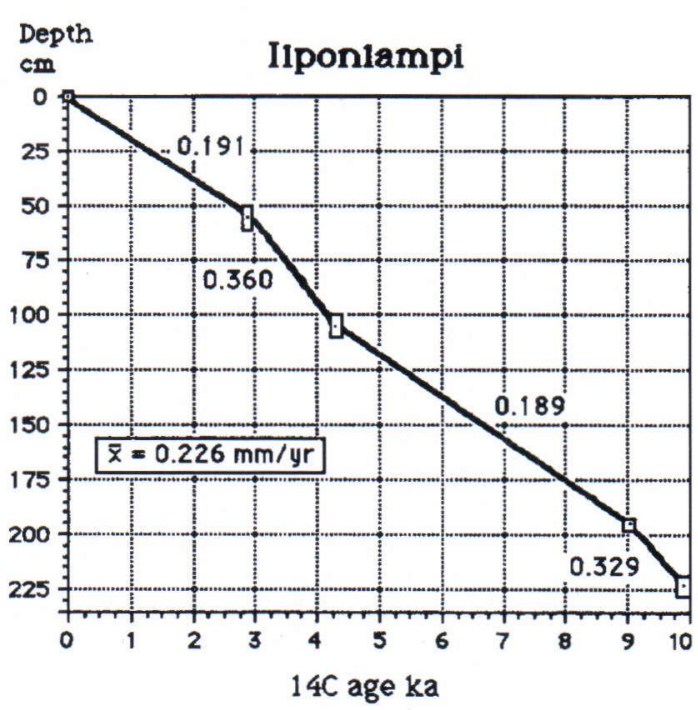

Fig. 3. Sediment accumulation rate in Ilponlampi. The breadths of the symbols indicate the standard deviations of the uncorrected dates. 
ILPONLAMPI $66^{\circ} 07^{\prime} 24^{\prime \prime} \mathrm{N}, 30^{\circ} 14^{\circ} 57^{\circ} \mathrm{E}, \mathrm{c}, 285 \mathrm{~m}$ asl.

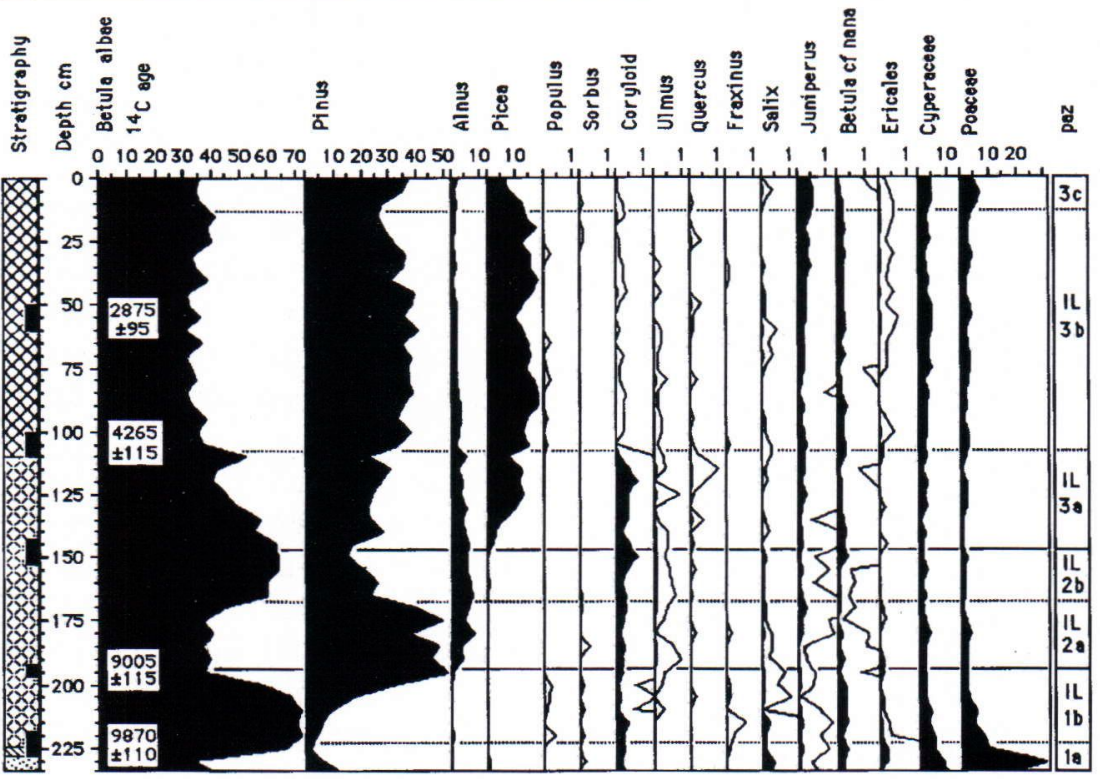

Mud Silty gyttja $\quad{ }^{14} \mathrm{C}$-dating

国 Gyttja Silt

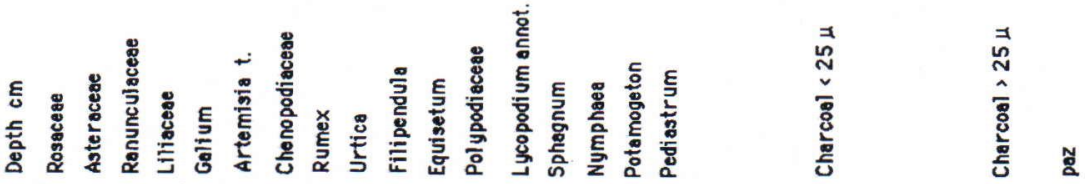

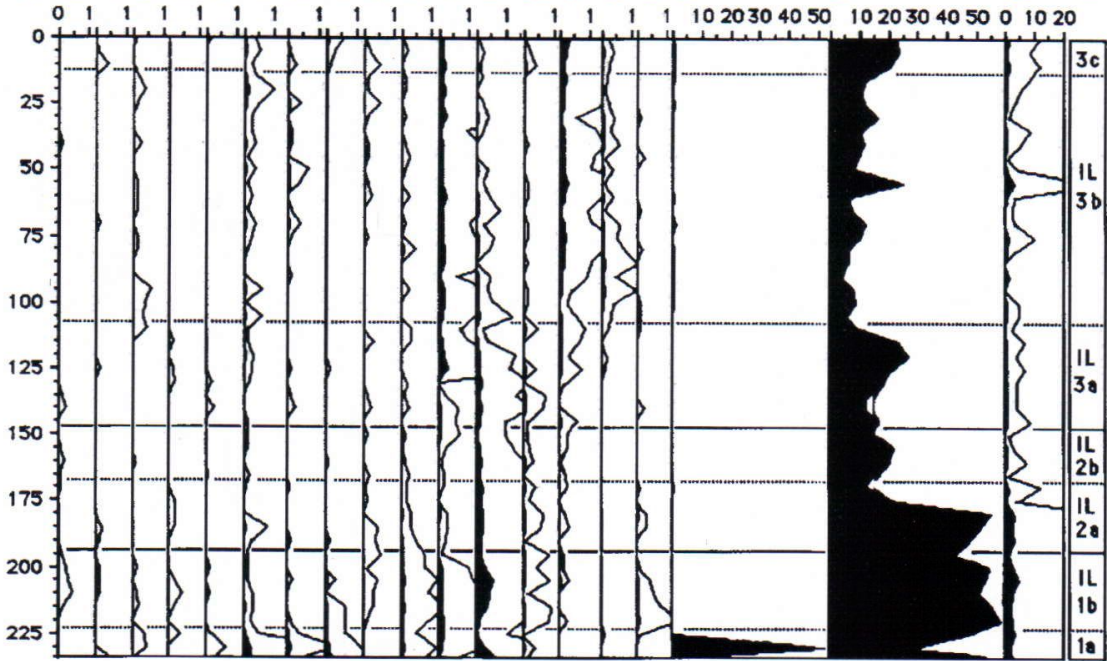

Fig. 4. Relative (\%) pollen diagram for the main taxa at Ilponlampi and charcoal diagram. The white silhouettes indicate values per mille. 
is available for the beginning of the spruce pollen curve, but an age 6540 B.P. can be achieved by interpolation. After the peak in Coryloid pollen (7.7 $\%)$, there is a very clear decrease in southern deciduous tree pollen at the paz IL $3 \mathrm{a} / \mathrm{b}$ boundary, about $4265 \pm 115$ B.P. In zone IL $3 \mathrm{c}$, where the proportions of pine pollen increase and those of spruce pollen decrease, the two topmost spectra $(0$ - $5 \mathrm{~cm}$ ) contained a few grains of Cerealia-type pollen (not presented in the diagram).

The yield of macroscopic remains was very poor and provided hardly any additional information to that of the microscopic analyses. The only Potamogeton species found was $P$. natans L. which occurred in the samples between 190-150 cm, i.e. during paz IL 2. This is contemporaneous with the time when $P$. natans has earlier been found to have been most common in the lakes of Kuusamo (Vasari 1962).

One seed each of Carex rostrata or lasiocarpa, Menyanthes trifoliata and Nymphaea cf. candida each were found during paz IL 3. The only other identifiable macroremains were those of Pinus sylvestris, Picea abies and Betula cf. pubescens, at levels where pollen analysis also indicated their presence. Additionally, small fragments of mosses were found throughout the sequence.

There were no diatom remains at the bottom of the core, and because of pronounced dissolving of material, counting was difficult even at $215 \mathrm{~cm}$. The species counted at 215 and $210 \mathrm{~cm}$ were mostly ones that demand high conductivity and can also be found in brackish water, e.g. Mastogloia smithii var. lacustris Grunow and Opephora martyi Heribaud (Fig. 5). The diatom-inferred $\mathrm{pH}$ at this stage was 8.3 (index $\alpha$ ) or 7.8 (index B)(Fig. 6), the main species being the alkaliphilous-indifferent Neidium affine (Ehrenberg) Pfitzer.

The next phase, 205 to $175 \mathrm{~cm}$, has a fairly constant flora, still with the benthic Neidium affine as the main species, but the alkaliphilous Anomoeoneis exilis (Grunow) Ross (also benthic) and the epiphytic alkaliphilous-indifferent Cymbella spp. are the best markers. Cymbella species becomes more dominant upwards in this phase (Fig. 7). The
Depth $\mathrm{cm}$

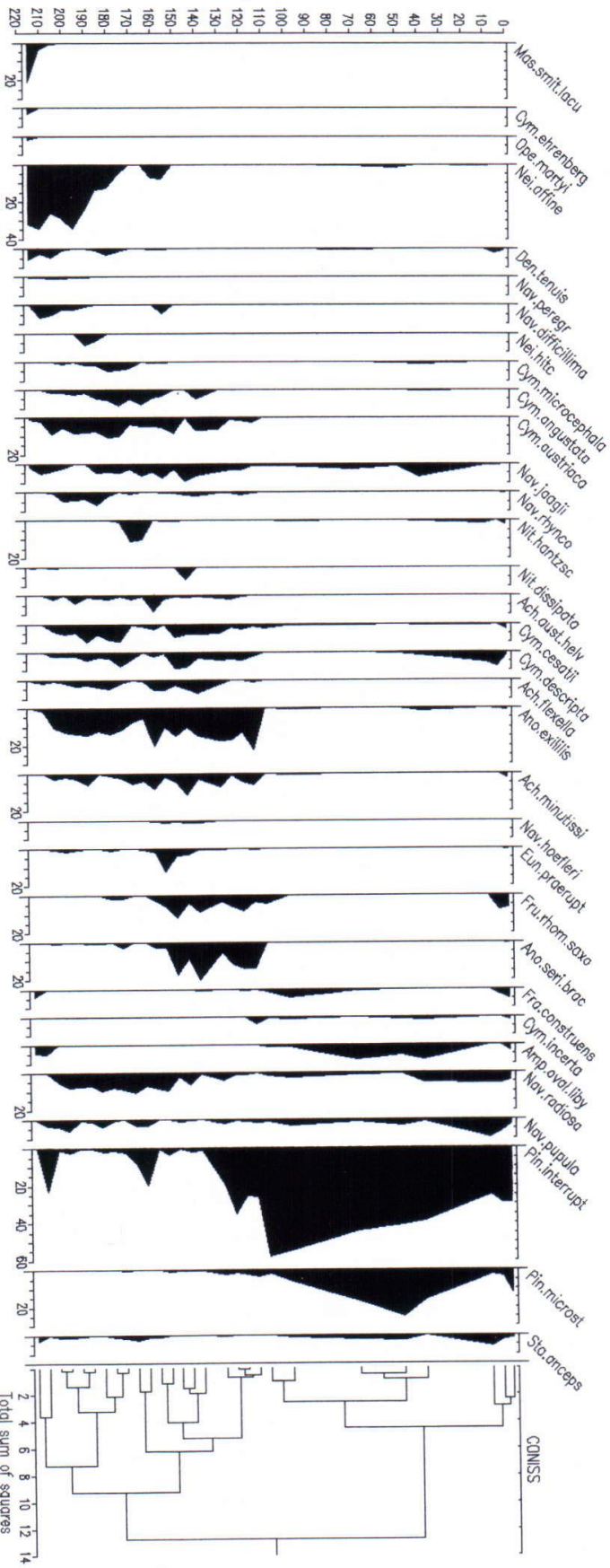

Fig. 5. Relative diatom diagram for Ilponlampi. 


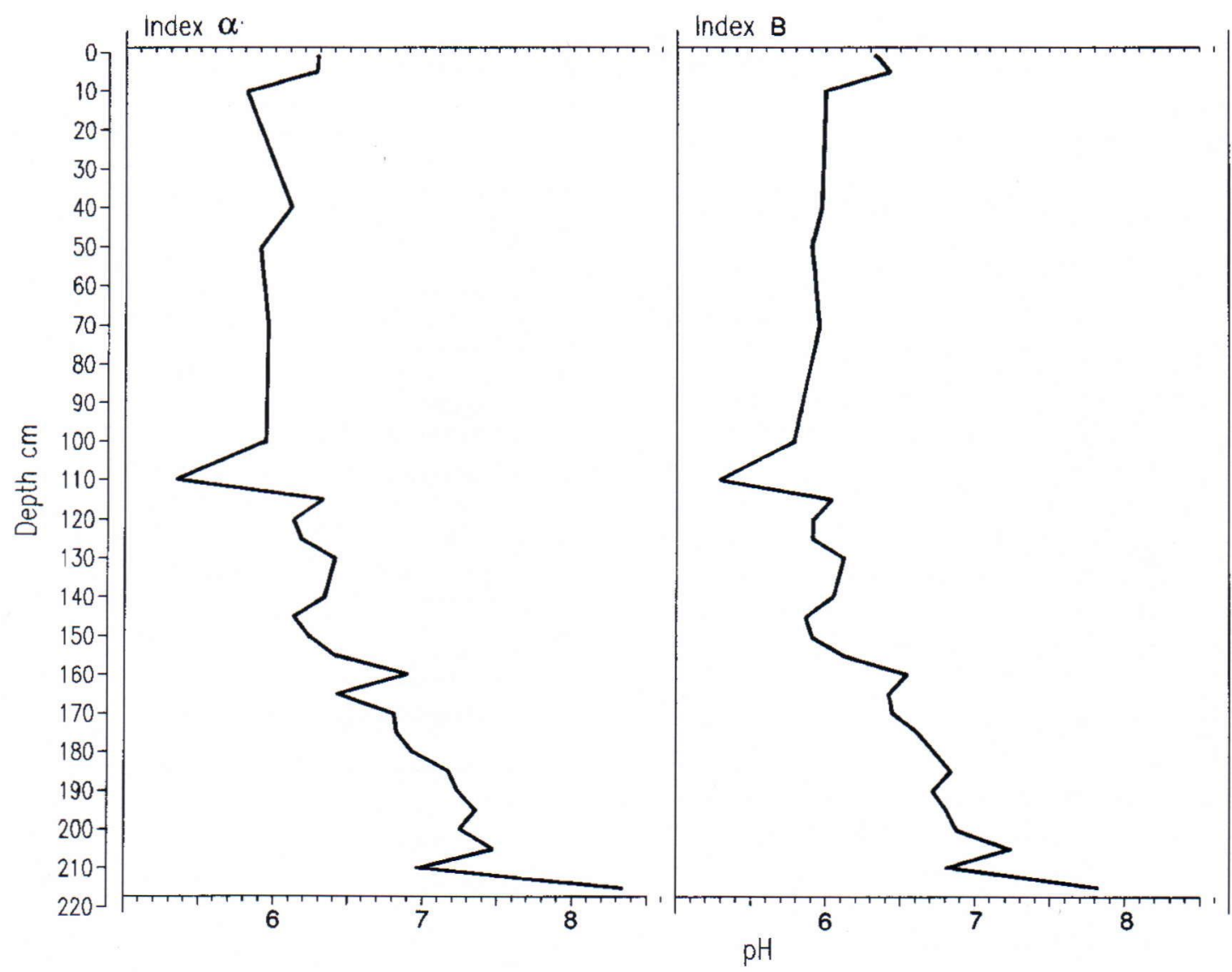

Fig. 6. Reconstructed pH succession in Ilponlampi.

most important Cymbella species, $C$. angustata (W. Smith), Cleve and C. austriaca Grunow, are common in mountain lakes with moderate conductivity, but the presence of Cymbella cesatii (Rabenhorst) Grunow and Cymbella descripta (Hustedt) Krammer \& Lange-Bertalot indicate an increasing humus content in the water.

Acidophilous taxa became more predominent from 170 to $115 \mathrm{~cm}$ (Fig. 8), Anomoeoneis serians var. brachysira (Brebisson) Cleve, Frustulia rhomboides var. saxonica Rabenhorst and Eunotia praerupta Ehrenberg being good examples of the diatom flora of that time. Their maxima extend from 150 to $115 \mathrm{~cm}$.

The progress of acidification reaches its climax at $110 \mathrm{~cm}$, where $86 \%$ of the frustules counted belonged to acidophilous species (Fig. 8). From that level upwards begins the period of benthic, acidophilous Pinnularia spp., in which the main species are Pinnularia interrupta W. Smith and Pinnularia microstauron (Ehrenberg) Cleve, the latter reaching its maximum at $50 \mathrm{~cm}$. Other coexisting species are mainly acidophilous or indifferent. The alkaliphilous Fragilaria contruens (Ehrenberg) Grunow is still quite abundant at the beginning of the phase, however, as is the alkaliphilous Amphora ovalis var. libyca (Ehrenberg) Cleve. This long phase, ending at 10 $\mathrm{cm}$, was not uniform, however, being interrupted by levels without diatom frustules, so that the 20 , $30,60,80$ and $90 \mathrm{~cm}$ samples did not contain enough diatoms to count. 


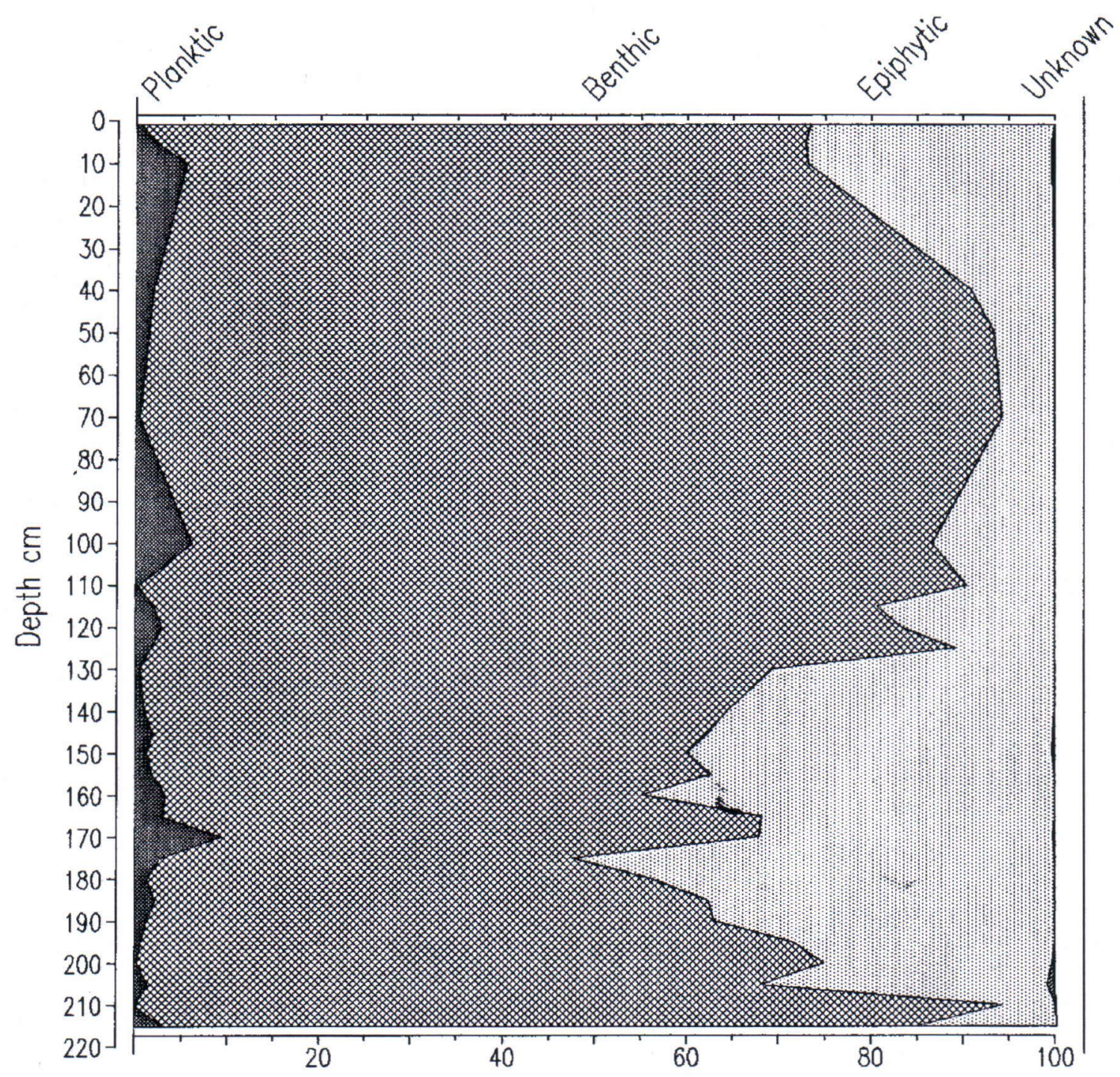

Fig. 7. Life-form succession of the diatom flora in Ilponlampi.

\section{DISCUSSION}

Age of the events

Both the radiometric and the pollen results indicate that the Ilponlampi sequence covers the whole of the Post-Glacial history of the basin. The delta 13-C data fall in the range for lakes having sediments free of carbonate, a fact that can be interpreted as a result of a limited influx of older carbon from either the groundwater or the organic bottom sediments, i.e. metabolic carbon. The tendency for a slight decrease in the delta $13-\mathrm{C}$ values upwards suggests that the role of hard water was negligible during the first 


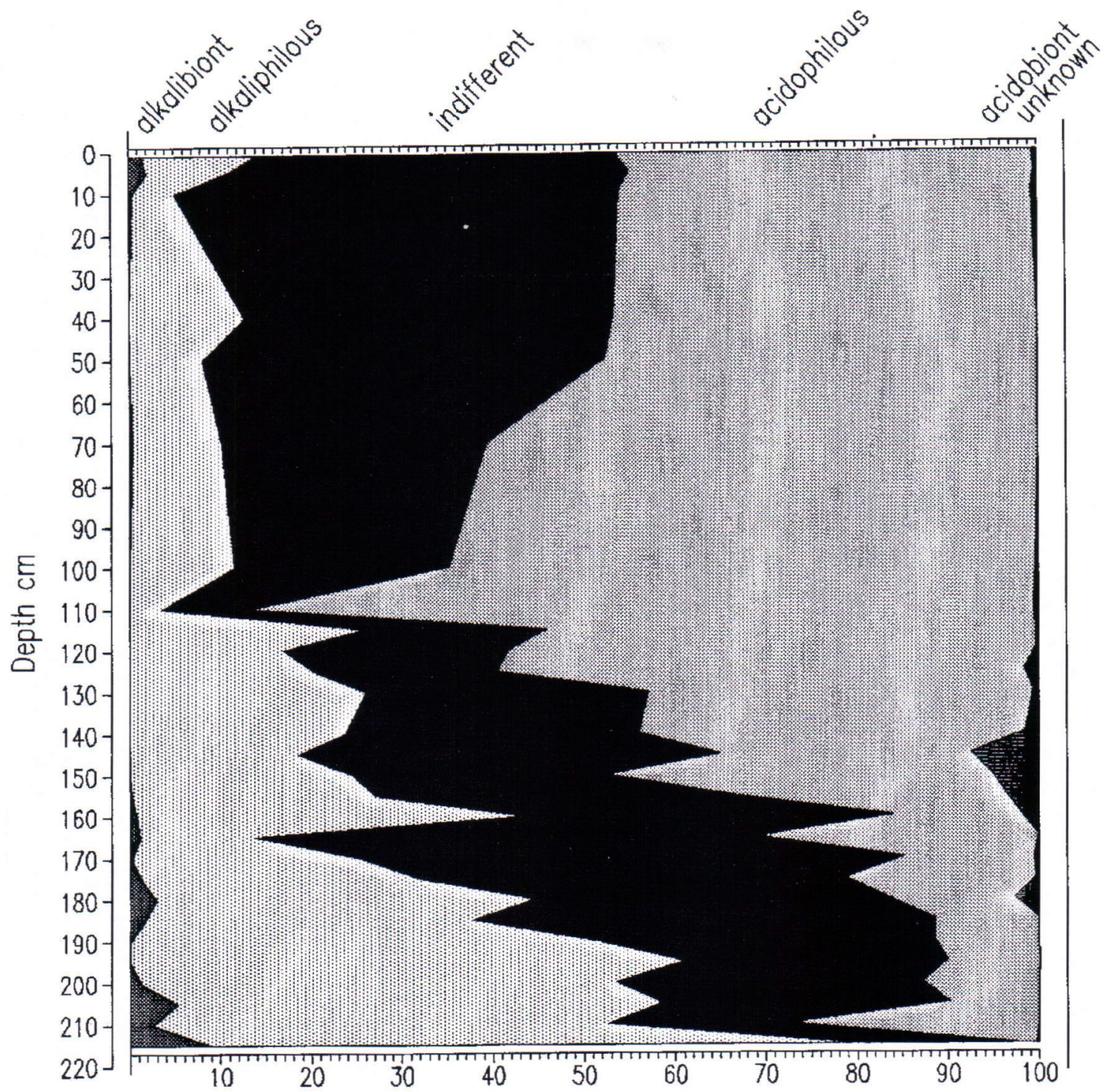

Fig. 8. Environmental requirements of the diatom flora of Ilponlampi.

stage of Holocene but increased steadily later on, possibly causing greater apparent $14-\mathrm{C}$ ages.

The 14-C results are slightly older than expected, the difference being only a few hundred years in the bottom sample but increasing to several hundred years higher up in the deposit. Both the start of organic sedimentation and the dated horizons for the spread of given tree species are older than is generally found on the Finnish side of the border (see Hicks 1975; Heikkinen \& Kurimo 1977; Koutaniemi 1979; Seppälä \& Koutaniemi 1985; Huttunen 1987). The results nevertheless coincide fairly well with those obtained earlier in the Russian part of the Kuusamo upland area (Jelina 1981, 
1985; Vasari 1993) or are only slightly older. It seems quite probable, in fact, that the immigration of new biota, which obviously took place in an east-west direction, will have resulted in a time gradient for the corresponding 14-C dates.

\section{Vegetation history}

The general trends in the pollen diagram follow the Holocene vegetational features described for NE Finland by Vasari (1962) and for northern Russian Karelia by Jelina (1981, 1985). Even the oldest microfossil sequences of Lake Ilponlampi do not reflect any of the characteristic Late-Glacial features known from the Salpausselkä foreland in eastern Finland (cf. Bondestam et al. 1994 and literature cited therein). The NAP-rich first phase of the diagram (IL 1a) must be regarded as the only reflection of the short-lived periglacial succession here, even though signs of a corresponding initial phase are lacking in NE Nuoruslampi, a pond 260 $\mathrm{m}$ higher on the top of the hill of Nuorunen studied by Huttunen \& Koutaniemi (1993).

Pollen of Sorbus and Populus, which are rather infrequent pollen taxa in this area, were found here as early as the Preboreal zone, most probably indicating local tree stands. This early colonization is equivalent to a palynological record for a site some $50 \mathrm{~km}$ westwards (Huttunen \& Huttunen 1989) and to a similar phenomenon in Finnish Karelia (Bondestam et al. 1994). After beginning of the birch forest maximum probably some 9800-9500 B.P., pine stands increased rapidly, almost simultaneously with the spread of alder around 9000-8500 B.P. This happened without the obvious asynchroneity generally observed at more southern localities (see Hyvärinen 1972; Tolonen \& Ruuhijärvi 1976), but resembling a case - also in timescale - at the southern coast of Finland (Korhola \& Tikkanen 1991).

The high proportion of large charcoal particles during the two first millenia of the Holocene probably indicates a higher intensity of forest fires during this dry period (see Vasari 1962; Yurkovskaya et al. 1989).
The spread of spruce at the expense of the broad-leaved trees probably took place about 6500-6000 B.P. The Coryloid pollen type was most likely produced by Corylus, but it remains uncertain whether it was growing at or near the site. In any case, its proportion reached higher figures than are generally found in the area (cf., however, diagram II in Vasari 1962). The decrease in southern deciduous trees about 4000 B.P. is striking, and the reason for it is more likely to have been climatic than edaphic. The change in the sediment at the same time may have been caused by the same environmental effect.

Sphagnum spores, an indication of mire vegetation, increase in amount with time through the sequence, especially during the last four thousand years. On the other hand, pollen of the Betula nanatype seems to have made up a small proportion of the pollen rain in the area all the time.

The decrease in spruce pollen together with increases in some of the palynological indicators of cultivation and in large charcoal particles in the uppermost part of the pollen diagram may well be connected with human activity, both in the area in question and in the direction of the prevailing winds. Slash and burn cultivation was practiced in the Kuusamo area from the late 17th until late 19th century (Kortesalmi 1969). Cerealia-type pollen, a clear sign of cultivation, was found near the surface.

\section{History of the lake}

Detrended Correspond Analysis, carried out in order to be able to present the development process in visible form (Fig. 9), yielded an X axis with a high eigenvalue 0.52 , and a second axis with an eigenvalue of 0.17 . The right-hand side of the $\mathrm{x}$ axis was marked by Cocconeis diminuta Pantocsek, Fragilaria leptostauron (Ehrenberg) Hustedt, Achnanthes sp., Amphora ovalis var. pediculus (Kutzing) Cleve, Cymbella ehrenbergii Kutzing, Opephora martyi, Caloneis obtusa (W. Smith) Cleve, Mastogloia smithii var. lacustris and Pinnularia nodosa Ehrenberg (mentioned in order of significance). This gives an impression of an 


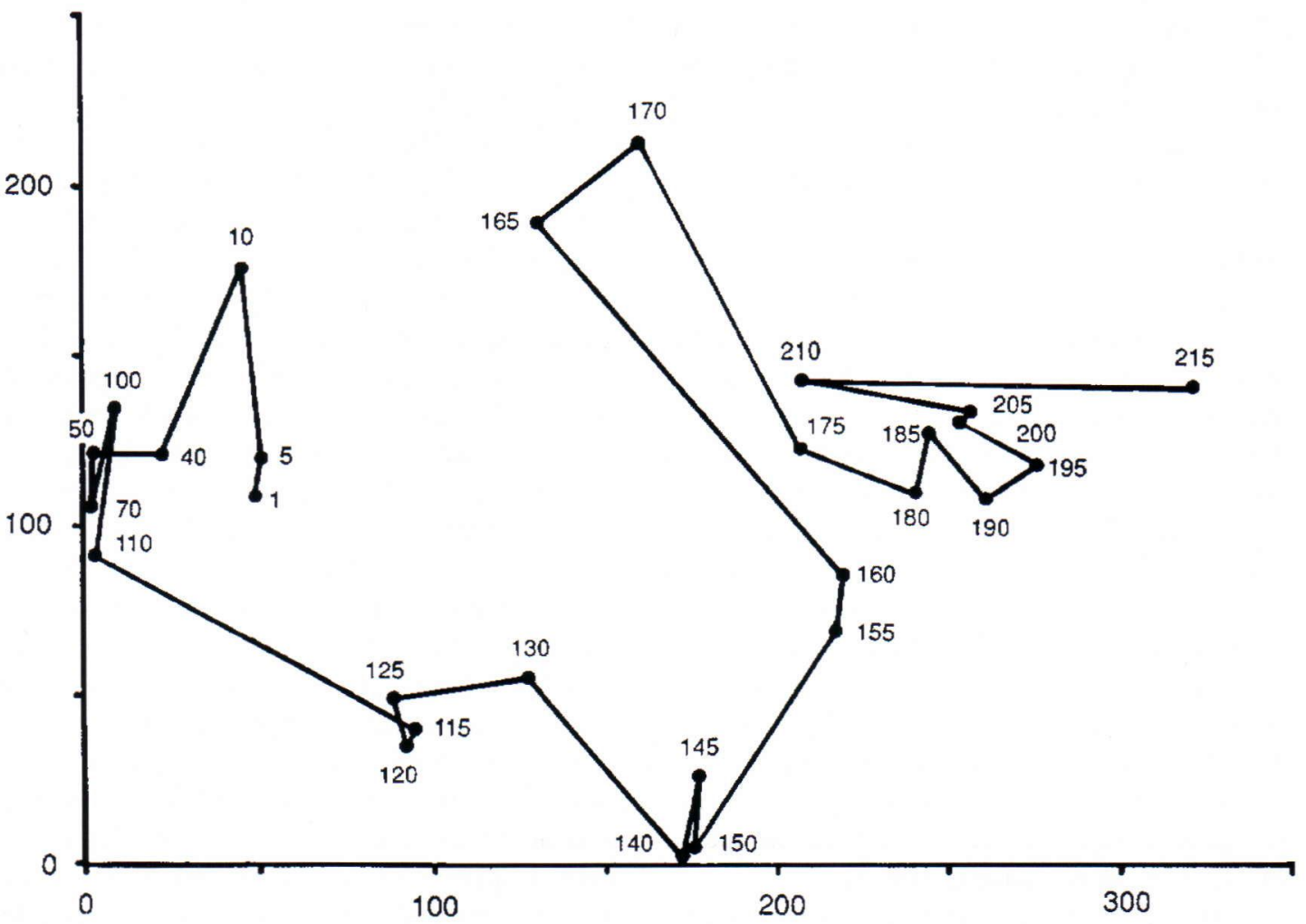

Fig. 9. DCA ordination of the diatom assemblages of Ilponlampi.

environment of high conductivity and clear water. Many of these species also played an important role in a pond producing calcareous sediment near Oulanka, NE-Finland (unpublished data of Eskonen).

The left side of the axis is formed by Caloneis alpestris (Grunow) Cleve, Anomoeoneis zellensis (Grunow) Cleve, Navicula phyllepta Kutzing, Cyclotella bodanica Grunow, Eunotia formica Ehrenberg, Navicula cuspidata (Kutzing) Kutzing, Aulacoseira ambiqua (Grunow) Simonsen, Gomphonema parvulum (Kutzing) Kutzing and Fragilaria pinnata Ehrenberg. Both Navicula species are encountered in brackish water, but are also found in eutrophic lakes, and the planktic $A$. ambiqua and $C$. bodanica are also common in eutrophic lakes. Eunotia formica and Anomoeoneis zellensis are satisfied with a lower conductivity, and Coloneis alpestris is common in lime-rich sediments.

It seems that the highly meaningful X axis mainly reflects environmental changes that caused the water quality to alter from hard to soft (see the description of lakes in prairies and various types of forest in North America, Koivo 1978). Both the generally decreasing amount of electrolytes in the drainage area (called 'natural oligotrophication of waters' by Vasari, 1962 for example) and the thickening of the isolating bottom sediment were instrumental in inducing this trend, which can be seen in the diatom assemblages as a movement from a Mastogloia smithii assemblage via Neidium affine to a northern alpine Cymbella assemblage between about 9500 and 5000 years B.P.

From about 4500 until about 3000 years B.P. the conductivity requirements of the communities remain quite constant. The climate was evidently cool and wet, and deciduous trees had diminished. 
From 5000 B.P. onwards increasing paludification of the surroundings, indicated by the rise in the Sphagnum curve, led to an increasing degree of dystrophy in the lake, as shown by the increased role of Nymphaea, for instance. The decrease in epiphytic diatoms may have been a result of the decrease in host macrophytes as a consequence of a change in the shape of the shore due to infilling processes. On the other hand, the increase in benthic forms may also have resulted from better preservation of the strong Pinnularia frustules (Engström \& Wright 1984). The trend alters markedly about 2000 years B.P. and again quite recently (at $10 \mathrm{~cm}$ level). Since there is not likely to have been any clear macroclimatic change during this phase, this may have been caused by minerals released from the vegetation in connection with forest fires (see Fig. 4).

The species at the top of the $\mathrm{Y}$ axis are Nitzschia gracilis Hantzcsh, Diatoma vulgaris Bory, Surirella linaris. constricta (Grunow) Hustedt, Fragilaria crotonensis Kitton, Nitzschia frustulum (Kutzing) Grunow, Pinnularia hemiptera (Kutzing) Cleve, Synedra acus Ehrenberg and Nitzschia hantzschiana Rabenhorst, all of which, except for $P$. hemiptera (indifferent), are alkaliphilous and usually require a high nutrient content. At the bottom of the axis are the species Navicula bryophila Petersen (acf), Eunotia exiqua (Brebisson) Rabenhorst (acf), Synedra ulna (Nitzch) Lange-Bertalot (ind), Gomphonema intricatum Kutzing (ind), Navicula hoefleri Cholnocy (acf-acb) and Cymbella norvegica Grunow (ind), reflecting oligotrophic, acidified water.

The $\mathrm{Y}$ axis, with its rather low eigenvalue, may reflect casual changes in the vegetation of the drainage basin, regulating the quantity and quality of the water inflow and the exposure of the lake to the wind (Meriläinen et al. 1982). The sudden rises in the curve are due to diatom assemblages with maxima of planktonic forms, indicating either more wind, more nutrients or more water. All these factors may have been caused by forest fires, for example. The very deepest part of the DCA curve is dated to the warm, dry period, and similar acidification at about the same time (6000-5000 B.P.) has also been reported by Tolonen et al. (1986) for Lake Työtjärvi. It is possible that the water level was at its lowest then and that the lake was surrounded by coniferous forests, which released acid needles, but it may also be that the original "clearwater alkalinity" had been exhausted by that time but that there were not yet sufficient quantities of humic substances to produce "humus water alkalinity".

The research at Ilponlampi forms a continuation to existing series of investigations into long-term acidification (e.g. Tolonen 1980). In order to be able to answer the question of human influence on the lake we would have had to count diatoms at $0.5-1 \mathrm{~cm}$ intervals in the topmost part of the core. There were probably more precise signs of human activity present there, but they were not revealed in this investigation. The influence of early cultures (slash-and-burn and the time before that) on small lakes in northern areas is still a potential topic for further research.

ACKNOWLEDGEMENTS: Sincere thanks are due to $D r$. Raivo Rajamäe for the radiocarbon dating and comments concerning the dates, to Annikki Vasari, M. Sc., for identifying the macro-remains, to Dr. Heikki Simola for commenting on the ms., and to the staff of Oulanka Biological Station. 


\section{REFERENCES}

Bondestam, K., Vasari, A., Vasari, Y., Lemdahl, G. \& Eskonen, K., 1994. Younger Dryas and Preboreal in Salpausselkä foreland, Finnish Karelia. Dissertationes Botanicae 234, 161-206.

Ekman, I. \& Iljin, V., 1991. Deglaciation, the Younger Dryas end moraines and their correlation in the Karelian A.S.S.R and adjacent areas. Geological Survey of Finland, Guide 32, 73-99.

Engström, D.R. \& Wright, H.E. Jr., 1984. Chemical stratigraphy of lake sediments. In: Elisabeth Y. Haworth \& John W.G. Lund (eds.), Lake sediments and environmental history. Leicester University Press. The Pitman Press, Bath.

Eurola, S. \& Vorren, K.-D., 1980. Mire zones and sections in North Fennoscandia. Aquilo Series Botanica 17, 39-56.

Heikkinen, O. \& Kurimo, H., 1977. The post-glacial history of Kitkajärvi, North-eastern Finland, as indicated by trend-surface analysis and radio-carbon dating. Fennia 153, 1-32.

Hicks, S., 1975. Variations in pollen frequency in a bog at Kangerjoki, N.E. Finland during the Flandrian. Commentationes Biologicae 80, 1-28.

Huttunen, A., 1987. Kasvillisuuden kehitys Riistunturin alueella. Lic. Phil. thesis, University of Oulu, Department of Botany, $72 \mathrm{p}$.

Huttunen, A. \& Huttunen, R., 1989. Kuusamon Valtavaaran alueen kasvillisuuden historia. Oulun yliopiston Oulangan biologisen aseman monisteita 13, 19-24.

Huttunen, A. \& Koutaniemi, L., 1993. A palynological record of a pond on Mount Nuorunen, East Fennoscandia. Oulanka Reports 12, 21-24.

Huttunen, A. \& Vasari, Y., 1994. Kasviretki Nuoruselle ja Tavajärvelle itäiseen Kuusamoon. (Abstract: Botanists in Nuorunen-Tavajärvi region, Kuusamo, Russian Karelia). Aquilo Series Botanica 33, 35-39.

Hyvärinen, H., 1972. Flandrian regional pollen assemblage zones in eastern Finland. Commentationes Biologicae 59, 1-25.

Jelina, G.A., 1981. Principles of and methods for reconstruction and mapping of the Holocene vegetation. (in Russian). - Academy of Sciences USSR, Karelian Branch, Institute of Biology, 1981, 1-159.

Jelina, G.A., 1985. The history of vegetation in Eastern Karelia (USSR) during the Holocene. Aquilo Series Botanica 22, 1-36.

Kalliola, R., 1939. Pflanzensoziologische Untersuchungen in der alpinen Stufe Finnisch-Lapplands. Annales Botanici Societatis Zoologicae-Botanicae Fennicae Vanamo 13, 1-328.

Koivo, L., 1978. Species diversity in net diatom plankton of some lakes of prairie, deciduous forest and coniferous-deciduous forest regions of central North America. Annales Botanici Fennici 15, 138-146.

Korhola, A.A. \& Tikkanen, M.J., 1991. Holocene development and early extreme acidification in a small hilltop lake in southern Finland. Boreas 20, 333-356.

Kortesalmi, J.J., 1969. Suomalainen huuhtaviljely. Kansatieteellinen tutkimus. (Summary: Huuhtaviljely of the Finns. An ethnographic study). Acta Societas Historicae Ouluensis, Scripta Historica 2, 278-362.

Koutaniemi, L., 1979. Late-glacial and post-glacial development of the valleys of the Oulanka river basin, north-eastern Finland. Fennia 157, 13-73.

Krammar, K. \& Lange-Bertalot, H. (eds.) 1986-1992. Susswasserflora von Mitteleuropa 2/1-2/4. Bacillariophyceae. Gustav Fisher Verlag. Stuttgart. New York.

Meriläinen, J., 1967: The diatom flora and hydrogen ion concentration of the water. Annales Botanici Fennici 4, 51-58.

Meriläinen, J., Huttunen, P. \& Pirttiala, K., 1982. The effect of land use on the diatom communities in lakes. Hydrobiologia 86, 99-103.

Mölder, K. \& Tynni, R., 1967-1973. Über Finnlands rezente und subfossile Diatomeen I-Vii. Bulletin of the Geological Society of Finland. 39: 199-217, 40: 151-170, 41: 235-251, 42: 129-144, 43: 203-220, 44: 141-149, 45: 159-179.

Renberg, J. \& Hellberg, T., 1982. The pH history of lakes in southwestern Sweden, as calculated from subfossil diatom flora of the sediment. Ambio 11, 30-33.

Saarnisto, M., 1991. Chronology of the Salpausselkä end moraines in Finland, and the fluctuation of Baltic Ice Lake levels. Geological Survey of Finland, Guide 32, 7-23.

Sandman, O., Eskonen, K. \& Liehu, A., 1990. The eutrofication of Lake Särkinen, Finland and the effects of lake aeration. Hydrobiologia 214, 191-199.

Seppälä, M. \& Koutaniemi, L., 1985. Formation of a string and pool topography as expressed by morphology, stratigraphy and current processes on a mire in Kuusamo, Finland. Boreas 14, 287-309.

Stockmarr, J., 1971. Tablets with spores used in absolute pollen analysis. Pollen et Spores 13, 615-621.

Tolonen, K., 1980. Pollen, algal remains and macrosubfossils from Lake Gallträsk, S. Finland. Annales Botanici Fennici 4, 220-416.

Tolonen, K., Liukkonen, M., Harjula, R. \& Pätilä, A., 1986. Acidification of small lakes in Finland documented by sedimentary diatom and chrysophycean remains. In: Smoll, J.P., Battarbee, R.W., Davis, R.B. \& Meriläinen, J. (eds.), Diatoms 
and Lake Acidity. Dr. W. Junk Publishers, Dortrecht. Tolonen, K. \& Ruuhijärvi, R., 1976. Standard pollen diagrams from the Salpausselkä region of Southern Finland. Annales Botanici Fennici 13, 155-196.

Vasari, Y., 1962. A study of the vegetational history of the Kuusamo district (North East Finland) during the Late-quaternary period. Annales Botanici Societatis 'Vanamo' 33 (1), 1-140 + Appendix.

Vasari, Y., 1993. Jääkaudestanykyaikaan. In: Koutaniemi, L., Systra, Y., Kuusela, K. \& Shustov, J. (eds.):
Paanajärvskii Natzionalii Park - Paanajärven Kansallispuisto, 41-48. Koillissanomat, Kuusamo.

Vasari, Y. \& Huttunen, A., 1984. The bedrock and Quaternary botany of the Koillismaa region. Oulanka Reports 5, 54-57.

Yurkovskaya, T.K., Elina, G.A. \& Klimanov, V.A., 1989. Vegetation and paleogeography of forest and mire ecosystems on the right bank of the Pinega River (The Arkhangelsk Region). Botanitseskij Zurnal 74, 12, 1711-1725. (In Russian with English summary). 